\title{
A ROMAN PERIOD SUNKEN HOUSE FROM BELADICE ${ }^{1}$
}

\author{
J A ROSLAVA RUTTKAYOVÁ ${ }^{(0)}$ - MA T E J R T T K A Y (i)
}

\begin{abstract}
The present study discusses the inventory of finds from a sunken house that decayed in the last third of the $3^{\text {rd }} \mathrm{c}$. or the first half of the $4^{\text {th }} \mathrm{c}$. The feature was investigated in 2010. The backfill layers contain a relatively large number of archaeological finds - pottery, glass, bronze, iron, bone and antler artefacts. Specifically, the collection of finds includes a coin, bone and bronze needles, spindle whorls, an amulet, iron knives, nails and fragments of tools. The analysis of pottery shows that the majority of ceramics were used for dining purposes while larger vessels - storage containers are rare. Only a minor part of the pottery finds from the feature are Roman imports. Special attention is paid to the iron amulet box and the fragment of a clay vessel with a rooster-like (or hen-like) spout. The research together with other surveys in the Upper Žitava region corroborates the view that - contrary to previous beliefs - the region was densely settled from the end of the $2^{\text {nd }} \mathrm{c}$. to the $5^{\text {th }} \mathrm{c}$.
\end{abstract}

Keywords: Western Slovakia, Barbaricum, Late Roman Period, sunken house, Germanic and Roman finds.

A significant part of Karol Pieta's research interests was focused on the study of the Roman Period and the Migration Period. Together, almost forty years ago, we researched an important settlement dated back to the $3^{\text {rd }}-5^{\text {th }} \mathrm{c}$. in Nitra-Párovské Háje (Pieta/Ruttkay 1997). In 2009 and 2010, in turn, together with our colleagues, we had an opportunity to investigate a similar settlement in Beladice in the Upper Žitava Region. Out of respect for Karol Pieta, we would like to present one of the features discovered in this interesting settlement complex.

In 2009 and 2010, rescue excavations took place along planned R1 expressway Nitra - Selenec-Beladice - Tekovské Nemce (Fig. 1). One of the most

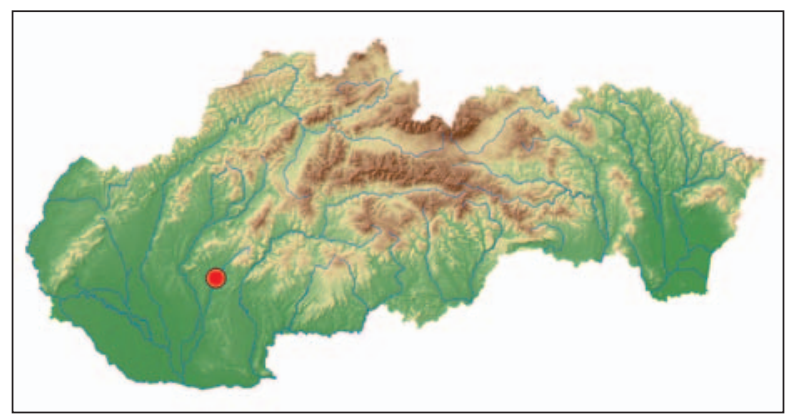

Fig. 1. Beladice. Localization on the map of the Slovak Republic. significant archaeological discoveries was made on a spot of 'Beladice junction', a site known since 1990 (Ruttkay/Ruttkayová 1992, 92). During the excavations, a part of the extensive, polyculture site endangered by the construction works was explored. A significant fragment of the explored area was covered by a settlement from the Roman and Migration Periods. Based on preliminary analysis, the settlement included 88 features -10 sunken houses, 12 deep storage pits, 6 free-standing furnaces (including a pottery kiln) and unspecified pits and free-standing postholes (Ruttkay et al. 2015). Among other things, the excavations provided a remarkable collection of finds from the Roman and Migration Periods (Fig. 2). Still, however, it remains uncertain whether the settlement was used continuously during these periods.

The site is located on the left bank - facing south of the Bocegaj creek in Dolina, partly in the floodplain. The micro-region abounds in archaeological sites (Bednár/Ruttkay 1991; Ruttkayová/Ruttkay 2015). Traces of prehistoric and early historic settlement can be found mainly on the opposite bank of the valley. Thus, it seems likely that in the Roman and Migration Periods both banks of the creek were inhabited.

The research in 2009 and 2010 was hampered by complex climatic, particularly pedologic, conditions on the site. Yellow-brown clayish layers

\footnotetext{
1 This work was supported by the Slovak Research and Development Agency under the Contract no. APVV-19-0563 and by VEGA project no. 2/0124/20.
} 


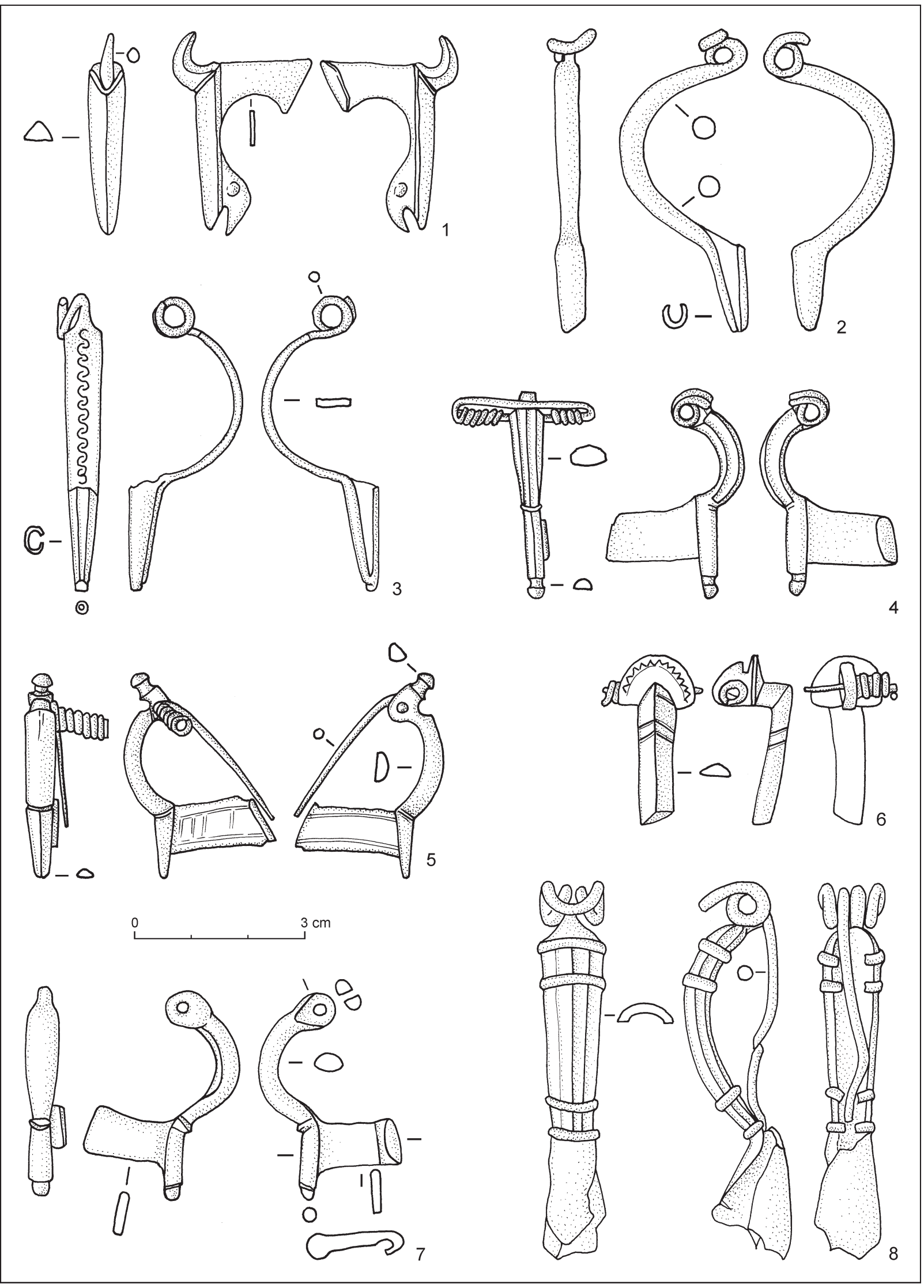

Fig. 2. Beladice. Selection of finds from different features from the site. 


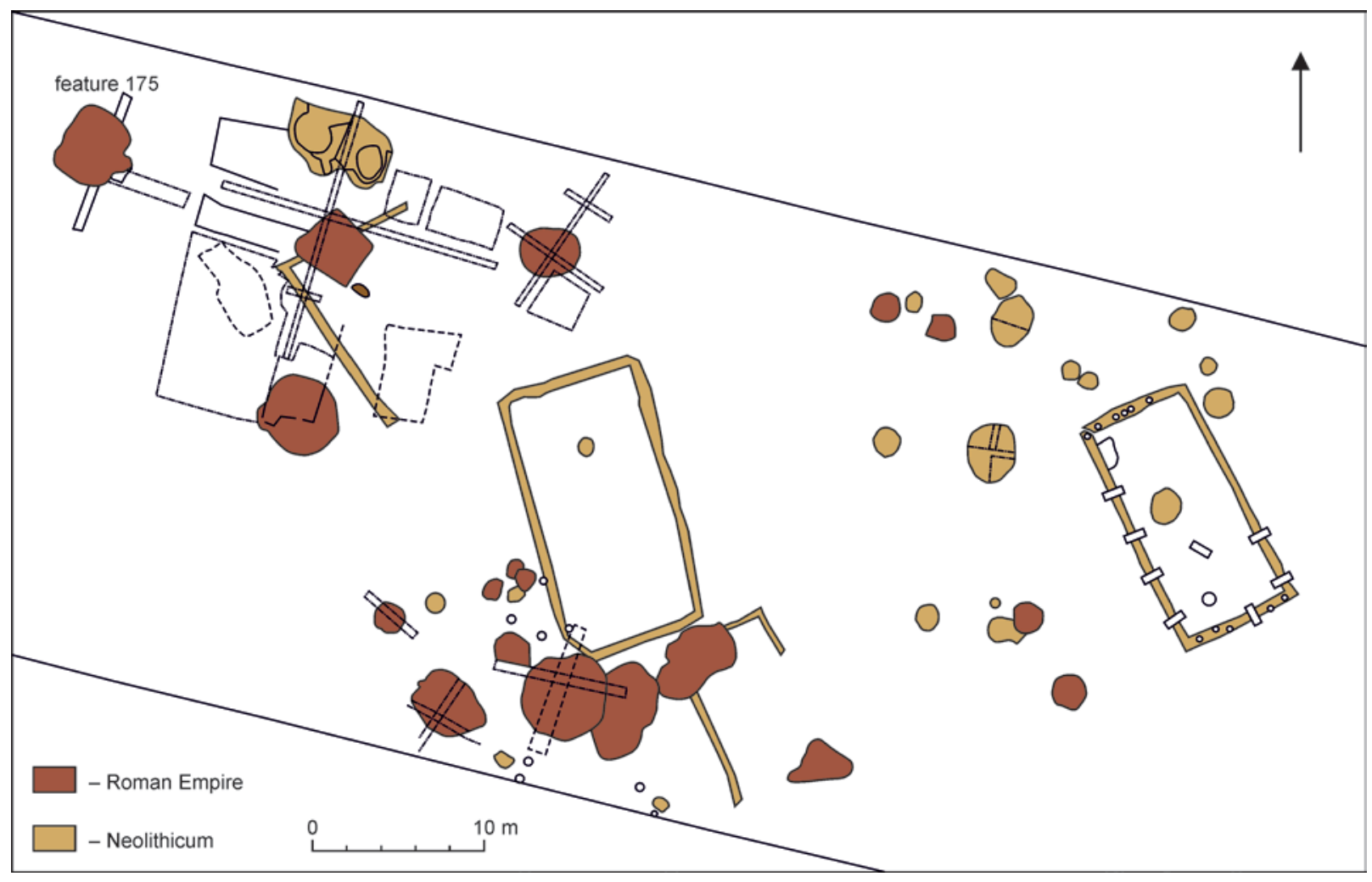

Fig. 3. Beladice. Plan of the eastern part of the site.

alternate here with a black-brown layer, mainly in the eastern part of the site. Apparently, in this (eastern) part of the site, there were no features. Since the layer below the topsoil contained finds, it was clear that the layer is not a subsoil. Thus, despite that the layer was on the limit of the construction works depth, we decided to explore the site using a network of trenches. As a result, we were able to identify numerous, originally 'invisible' features. Due to a considerable number of tangibles, feature no. 175 holds a special place among the discoveries (Fig. 3). The feature was captured thanks to trenches no. 110 and 111.

\section{DESCRIPTION OF FEATURE NO. 175}

A rectangular sunken house with slightly rounded corners (Fig. 4). Dims.: $420 \times 480 \mathrm{~cm}$, depth measured from the discovery level $82-102 \mathrm{~cm}$. The longer side is oriented along the NE-SW axis. On the flat bottom, we found 7 postholes: one in the middle of each of the shorter walls and two by each of the longer walls. The posts had diameters of $18-22 \mathrm{~cm}$ while the postholes were 38-62 cm wide. The postholes bottoms were captured at $42-62 \mathrm{~cm}$ below the floor level. The floor/bottom was made of smeared clay. In the western part, there was a red-burnt oval surface. On the eastern side, in turn, between a couple of postholes, there was an arched protrusion.

Finds were discovered at various levels of the backfill - i.e. slightly moved compared to the original position. In many cases, it was possible to match pottery shards from the upper layers with those from the bottom. Most likely, the finds reflect the activities of the settlement inhabitants around the feature during the Roman Period.

\section{Finds}

\section{Bone and antler}

1. Fragments of deer (?) antlers (inv. no. 029454_DP_2143a). Dims.: L. $7.61 \mathrm{~cm}$ (Fig. 5: 6).

2. Fragments of animal bone? (inv. no. 029454_DP_2143b). Dims.: L. $10.1 \mathrm{~cm}$ (Fig. 5: 7).

3. Fragments of a deer (?) antler (inv. no. 029454_DP_2884). Dims.: L. 8.4 cm (Fig. 5: 5).

4. A bone stick-shaped needle (inv. no. 029454_DP_2440), the needle butt is slightly widened and flattened. The item is circular in inter-section and has a pointed tip. Dims.: L. $10 \mathrm{~cm}$ (Fig. 6: 16).

5. A bone comb (inv. no. 029454_DP_2442), fragments of semi-circular plates of a three-layer, multi-part comb. 


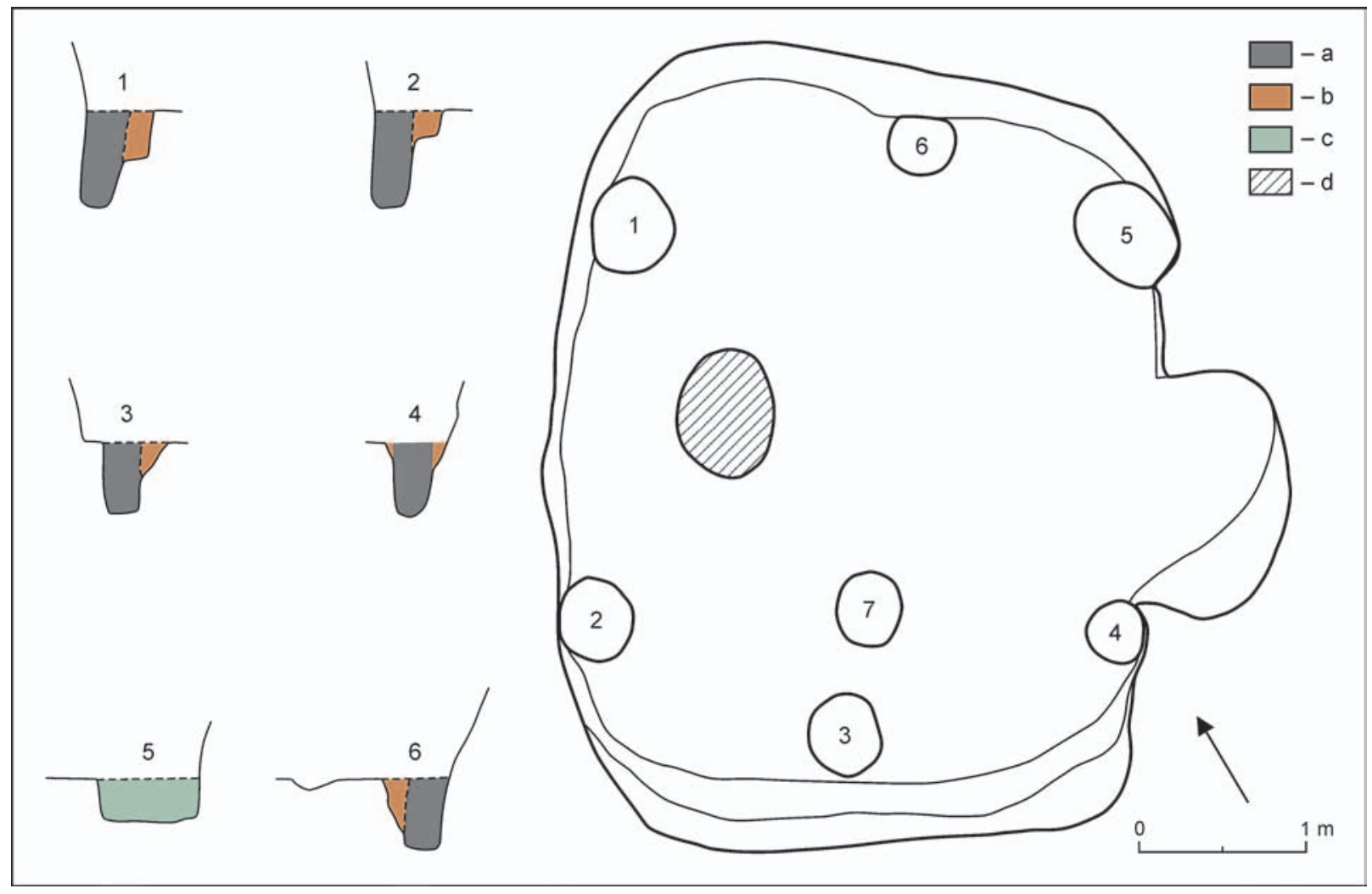

Fig. 4. Beladice. Feature no. 175. Legend: a - traces of the original post (grey); b - original post-hole (brown); c - not clear situation, possibly damaged by rodents; $\mathrm{d}$ - burned area.

The outer plate is decorated with concentric circles arranged in the shape of the X-letter (analogy Stráže: Zeman 2001, fig. 4: 19). In the middle plate, there was a preserved iron rivet. Dims.: L. $8.5 \mathrm{~cm}$, mass $6.369 \mathrm{~g}$; L. $7.5 \mathrm{~cm}$, mass $7.385 \mathrm{~g}$ (Fig. 6: 7).

\section{Metal}

6. A coin, antoninianus - Salonina (253-268), Galenius' wife (inv. no. 029454_DP_1882). Obverse: bust of the Empress with a tiara and a typical contemporary hairstyle, SALONINA AVG. Reverse: female silhouette (Juno?) holding, probably, a bowl in her left hand and a sceptre or a cornucopia in the right hand, inscription: IVNO... AVG. Dims.: D. $2.1 \mathrm{~cm}$, mass 3.056 g, composition: $\mathrm{Sn}$ 3.509, Ag 27.851, Pb 1.814, Cu 65.876 (Fig. 6: 6).

7. A bronze fitting (inv. no. 029454_DP_1897) with a hanging ring and a profiled body formed as a profiled knot. Composition: considerable addition of main elements - Sn 11.075, Pb 16.053, Zn 4.656, Cu 65.603. Dims.: L. $3.5 \mathrm{~cm}$, mass $3.005 \mathrm{~g}$ (Fig. 6: 4).

8. A silver conical clamp (inv. no. 029454_DP_1900) made of a gilded silver plate twisted into the shape of a cone. Its narrower side is attached to (inserted into?) a profiled ring. Composition: a considerable addition of main elements - Sn 10.072, Ag 51.364, Au 32.253, Cu 3.229. Dims.: L. 2.3 cm, mass 1.783 g (Fig. 6: 1).

9. A bronze needle (inv. no. 029454_DP_1898), circular in inter-section and slightly arched. One tip is narrowed and pointed while the other is thicker, rounded and has a narrow oval opening. Composition: considerable addition of main elements - Sn 27.922, Ag 0.406, $\mathrm{Pb}$ 0.661, Au 0.198, Zn 0.428, Cu 68.855. Dims.: L. 6 cm, mass $0.908 \mathrm{~g}$ (Fig. 6: 15).

10. A bronze (?) wire (inv. no. 029454_DP_1902a) thin and circular in inter-section, deformed. One end of the wire was hooked. Composition: considerable addition of main elements - Sn 2.036, Ag 0.113, Pb 0.733, Au 1.080, Zn 1.048, Cu 91.127. Dims.: L. 4.7 cm, mass 0.264 (Fig. 6: 2).

11. A fragment of a bronze item (inv. no. 029454_DP_1901) is an arched small rod, circular in inter-section with a bold tip (?). Dims.: L. $3.2 \mathrm{~cm}$, mass $3.816 \mathrm{~g}$.

12. A bronze plate (inv. no. 029454_DP_2439). A buckle fastening plate, thin rectangular plate bent in the middle and joint with two bronze rivets. Composition: considerable addition of main elements - Sn 12.669, Ag 0.334, $\mathrm{Pb}$ 2.661, Zn 8.146, Cu 70.800. Dims.: $2.3 \times 1.7 \mathrm{~cm}$, mass $3.356 \mathrm{~g}$ (Fig. 6: 3).

13. A fragment of a bronze/copper plate (inv. no. 029454 DP_2452), thin rectangular plate (from a vessel?) covered with green patina. Composition: considerable addition of main elements - Sn 0.013, Ag 0.064, Pb 0.588, Zn 0.137, Cu 98.095. Dims.: $5 \times 1.7$ cm, mass 3.475 g (Fig. 6: 8).

14. An iron container, amulet box (inv. no. 029454 DP_1883). The cylindrical container is closed with a lid firmly attached to the container (due to corrosion?). In the middle of the lid, there is an arched ring made of 


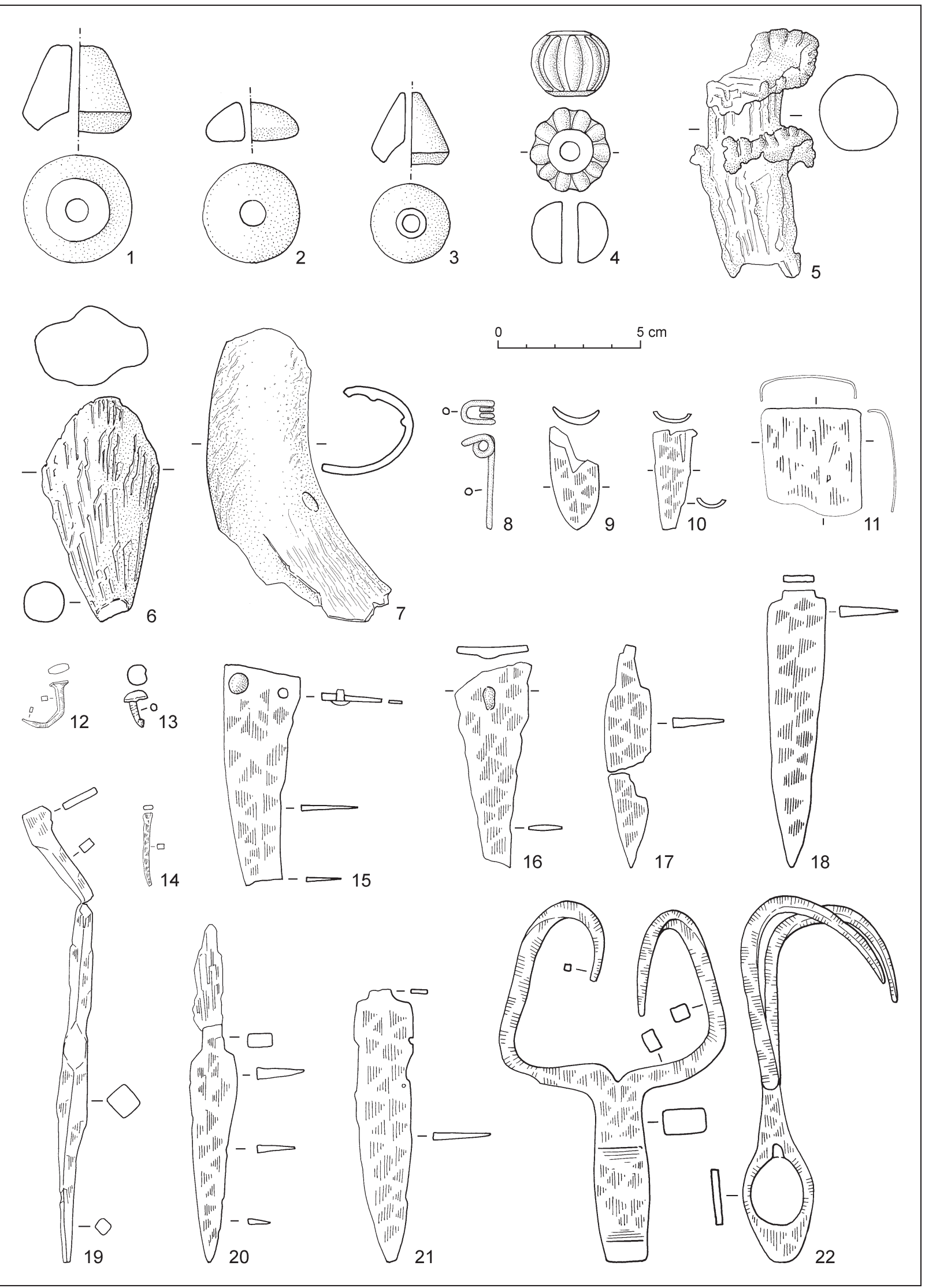

Fig. 5. Beladice. Feature no. 175. Selection of finds. 1-4 - ceramics; 5-7 - antlers/bone; 8-22 - iron. 


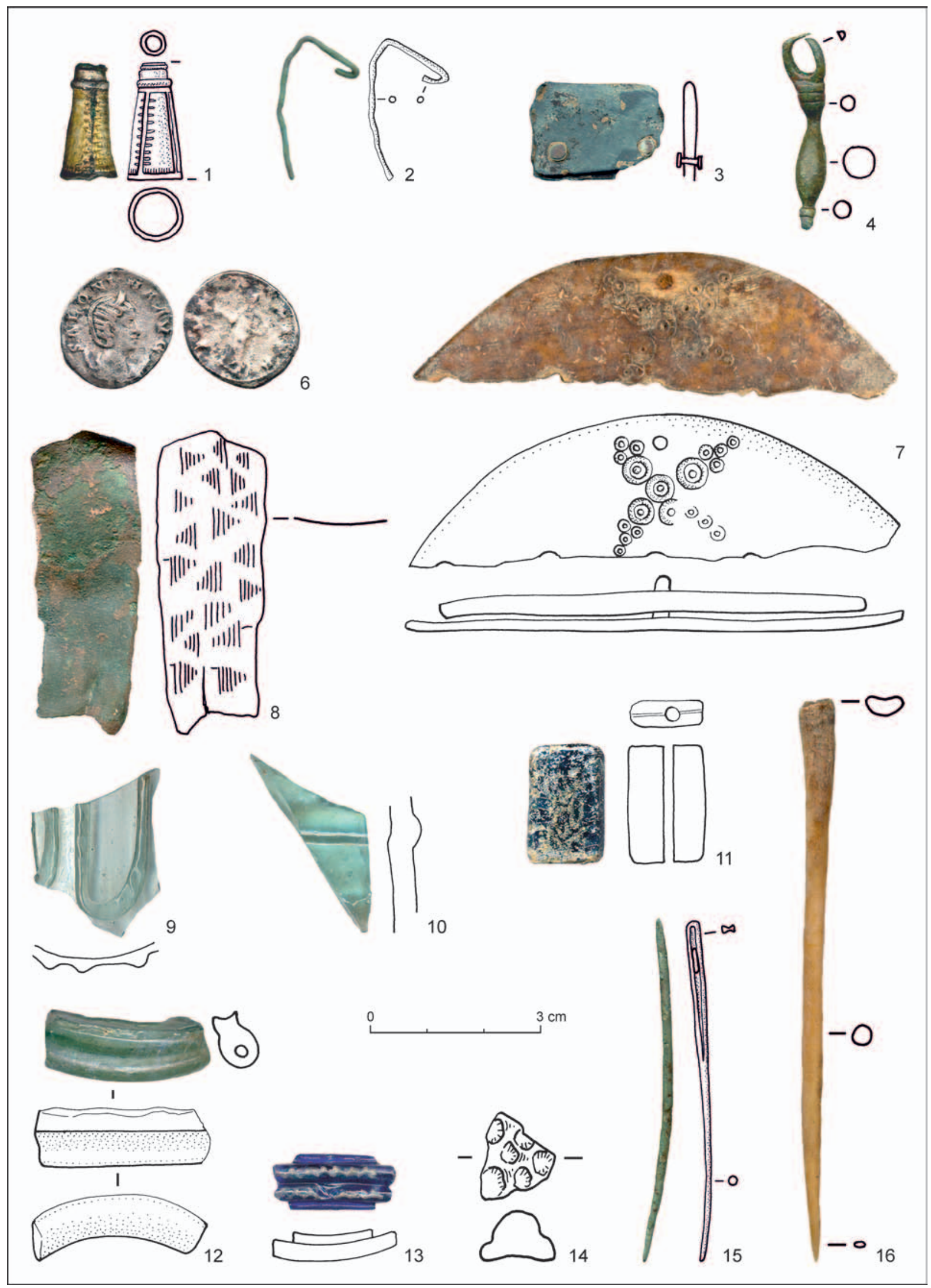

Fig. 6. Beladice. Feature no. 175. Selection of finds. 


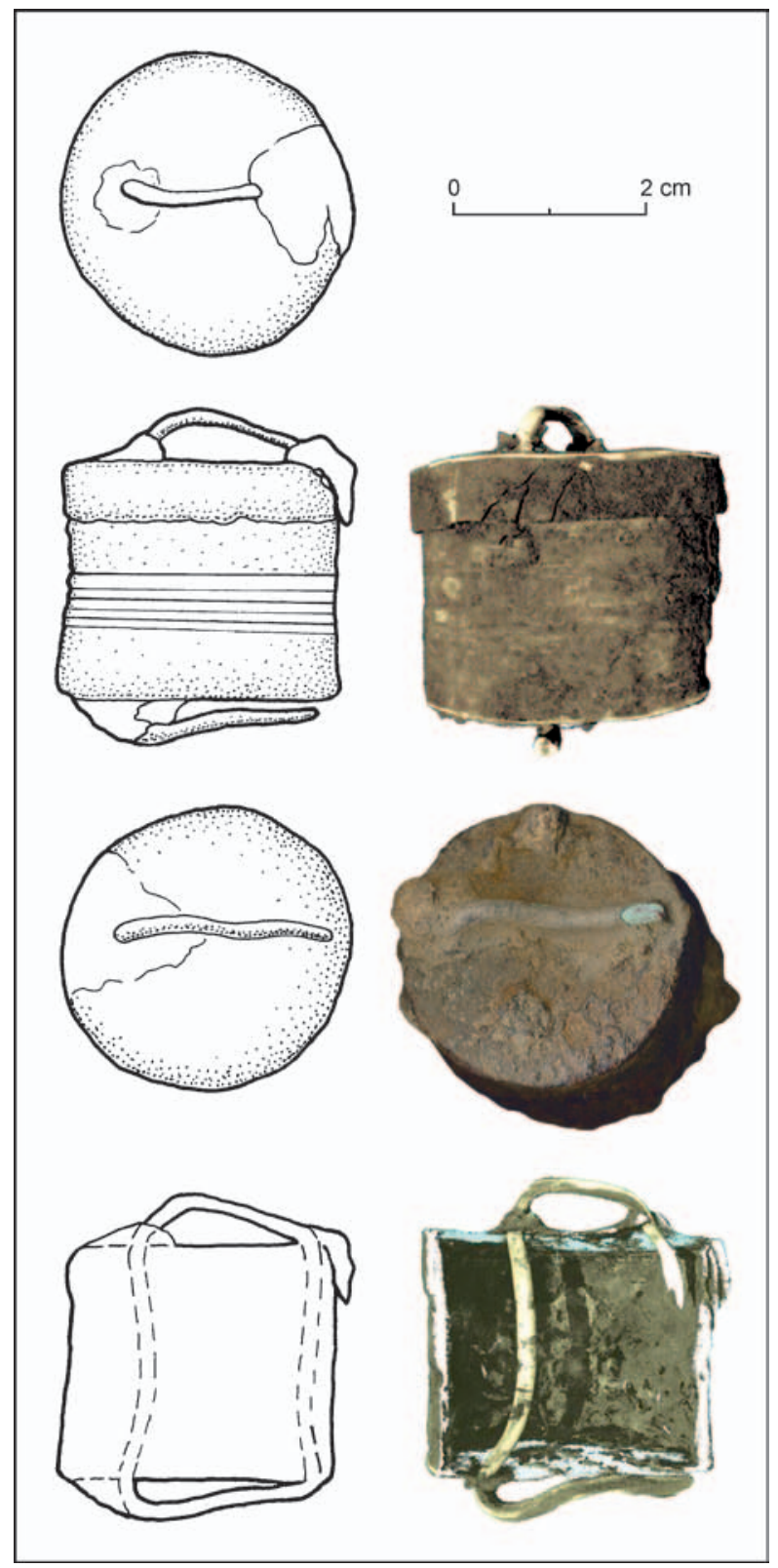

Fig. 7 Beladice. Feature no. 175. Amulet box.

bronze wire used for hanging and locking (?) the item. Dims.: H. 2.6 cm, diam. 3-3.3 cm (Fig. 7).

15. An iron 'fork' (inv. no. 029454_DP_2045) with a clamp fastening the tool to a wooden handle. Its flat side splits into two (probably not secondarily) bent teeth. Dims.: L. $13 \mathrm{~cm}$ (Fig. 5: 22).

16. An iron tool (inv. no. 029454_DP_1926). A surgical (?) tool, rectangular in inter-section with a split-tip and a square thorn. Dims.: L. $15.8 \mathrm{~cm}$, mass $29.517 \mathrm{~g}$ (Fig. 5: 19).

17. A fragment of an iron brooch (inv. no. 029454_DP_2449) with a quadruple winding, upper bow and a fragment of a pin. Dims.: L. 3.2 cm, mass 1.981 g (Fig. 5: 8).

18. A fragment of an iron wire/nail (inv. no. 029454 DP_1902b) a small rod rectangular in inter-section. Dims.: L. $1.8 \mathrm{~cm}$, mass $0.34 \mathrm{~g}$.
19. An iron nail (inv. no. 029454_DP_1903) with a flat, shieldlike head and a thorn circular in inter-section. Dims.: L. $5.9 \mathrm{~cm}$, mass $4.272 \mathrm{~g}$.

20. An iron nail (inv. no. 029454_DP_1906b) wider in the upper part and a thorn rectangular in inter-section. Dims.: L. 4 cm, mass 4.93 g.

21. An iron nail (inv. no. 029454_DP_1907) with a flat square head and a thorn square in inter-section. Dims.: L. $4.9 \mathrm{~cm}$, mass $5.133 \mathrm{~g}$.

22. An iron nail (inv. no. 029454_DP_1911a) with a flat narrow rectangular head and a thorn square in intersection. Dims.: L. $5 \mathrm{~cm}$, mass 4.75 g (Fig. 5: 12).

23. An iron item - sickle? (inv. no. 029454_DP_1905), a slightly bent (sickle-like) plate with an iron rivet and an opening for another rivet on one end. Dims.: L. $7.1 \mathrm{~cm}$, mass $17.036 \mathrm{~g}$ (Fig. 5: 15).

24. An iron item (inv. no. 029454_DP_1906a), a triangle plate with an opening for a rivet. Dims.: L. $7.1 \mathrm{~cm}$, mass $15.47 \mathrm{~g}$.

25. A fragment of an iron drill tip (inv. no. 029454_DP_1911b). Dims.: L. 3.6 cm, mass 6.737 g (Fig. 5: 9).

26. An iron rivet/nail? (inv. no. 029454_DP_2450) with a shield-like head and a short thorn bent at the end. Dims.: L. 1.3 cm, mass 0.762 g (Fig. 5: 13).

27. An iron nail (inv. no. 029454_DP_2451) is a small rod, rectangular in inter-section. Dims.: L. $5.1 \mathrm{~cm}$, mass $4.251 \mathrm{~g}$ (Fig. 5: 14).

28. An iron item (inv. no. 029454_DP_2393), a square plate fitting with bent edges and a small round opening. Dims.: $3.8 \times 3.5 \mathrm{~cm}$, mass $6.429 \mathrm{~g}$ (Fig. 5: 11).

29. An iron knife (inv. no. 029454_DP_1908), a flat tang with a fragment of a wooden handle. Dims.: L. $11.2 \mathrm{~cm}$, mass 13.985 g (Fig. 5: 20).

30. An iron knife (inv. no. 029454_DP_1909), a fragment of a flat tang. Dims.: L. 9.7 cm, mass 18.160 g (Fig. 5: 18).

31. An iron tool (inv. no. 029454_DP_1910), a fragment of a blade with a tip. Dims.: L. $3.4 \mathrm{~cm}$ (Fig. 5: 10).

32. An iron knife (inv. no. 029454_DP_1927), a blade. Dims.: L. $9.1 \mathrm{~cm}$, mass $13.486 \mathrm{~g}$ (Fig. $\overline{5}: 2 \overline{1})$.

33. An iron knife (inv. no. 029454_DP_2453) with a bent spine and a flat tang. Dims.: L. $7 \mathrm{~cm}$, mass $7.736 \mathrm{~g}$ (Fig. 5: 17).

34. An iron lump (inv. no. 029454_DP_2446). Dims.: $1.6 \times 1$ cm, mass $3.690 \mathrm{~g}$.

\section{Glass}

35. A fragment of a glass vessel (inv. no. 029454_DP_1881), thin, transparent glass with light-green or blueish reflexes, irregular. Its outer side is decorated with arched glass threads (rivets). Dims.: $3 \times 2.1 \mathrm{~cm}$, mass $2.147 \mathrm{~g}$ (Fig. 6: 9).

36. A fragment of a glass vessel (inv. no. 029454_DP_1913), thicker, transparent (colourless) triangle piece of glass. On the front, decorated with plastic trim. Dims.: $3.7 \times$ $1.2 \mathrm{~cm}$, mass $2.585 \mathrm{~g}$ (Fig. 6: 10).

37. A fragment of a dark blue bracelet (inv. no. 029454 DP_1914), type 13 according to Venclová (Březinová 2018, 55, fig. 3: 13). A fragment of a ring with two central ribs decorated with a white zigzag line. Dims.: L. $2.2 \mathrm{~cm}$, W. $0.8 \mathrm{~cm}$, mass $1.557 \mathrm{~g}$ (Fig. 6: 13).

38. A fragment of the rim of the bottom of the glass vessel (inv. no. 029454_DP_1915). A ring-like bolded bottom of a glass. Type? Thicker transparent glass of greenish 
colour and bent. Dims.: L. $3 \mathrm{~cm}$, W. $1 \mathrm{~cm}$, mass $3.492 \mathrm{~g}$ (Fig. 6: 12).

39. A glass bead (inv. no. 029454_DP_1921), blue opaque glass, flat square shape with rounded corners. In the middle, there is an opening. Dims.: $2.2 \times 1.4 \times 0.7 \mathrm{~cm}$, mass $3.236 \mathrm{~g}$ (Fig. 6: 11)

\section{Pottery}

40. A clay spindle whorl (inv. no. 029454_DP_1930), conical with longitudinal edges (facetted), black. Dims.: H. $2.8 \mathrm{~cm}$, mass 38.430 g (Fig. 5: 1).

41. A clay spindle whorl (inv. no. 029454_DP_2443), spherical, decorated with vertical grooves, dark-grey. Dims.: H. $2.2 \mathrm{~cm}$, mass $16.198 \mathrm{~g}$ (Fig. 5: 4).

42. A fragment of a clay spindle whorl (inv. no. 029454 DP_2444), conical, dark-grey (Lengyel culture?). Dims.: H. $2.5 \mathrm{~cm}$, mass $6.420 \mathrm{~g}$ (Fig. 5: 2).

43. A fragment of a clay spindle whorl (inv. no. 029454 DP_2445): conical, dark-grey. Dims.: H. $1.5 \mathrm{~cm}$, mass $5.769 \mathrm{~g}$ (Fig. 5: 3).

44. A fragment of clay vessel (inv. no. 029454_DP_1929), a rooster head (hollow) with a fragment of a comb preserved. Round indentations - eyes - and a fragment of a beak. Brick-colour. Dims.: H. 5 cm, W 4 cm (Pl. IV: 1).

45. A clay foot (inv. no. 029454_DP_1928), a vessel foot, full, cylindrical. Grey-brown colour. Dims.: H. $6.3 \mathrm{~cm}$ (Lengyel culture?).

46. A reconstructed vessel (Pl. I: 12).

47. A reconstructed vessel (Pl. I: 3).

48. Terra sigillata, 9 pcs (Pl. IV: 2, 4-10).

49. Pannonian brick-coloured pottery, 9 pcs (Pl. IV: 3 ).

50. Pannonian grey pottery, 7 pcs (Pl. IV: 11, 13).

51. Fine-grained grey pottery made with pottery wheel, 13 pcs (Pl. IV: 14).

52. Coarse grained light grey made with pottery wheel, 27 pcs.

53. Hand-made pottery, 893 pcs (Pl. I-III).

\section{Other}

53. A stone chip (inv. no. 029454_DP_2441), a narrow white blade made of flint? Dims.: L. $3.6 \mathrm{~cm}$, mass $1.492 \mathrm{~g}$.

54. Resin (inv. no. 029454_DP_2457), a small lump and irregular pieces of black (charred) resin. Dims.: $1.2 \times$ $0.9 \mathrm{~cm}$, mass $0.366 \mathrm{~g}, 0.66 \mathrm{~g}, 0.013 \mathrm{~g}$ (Fig. 6: 14).

\section{ANALYSIS AND INTERPRETATION}

The sunken house represents type III according to T. Kolnik $(1998,145)$ or type C1 according to A. Leube $(2009,147,148$, fig. 99) or type B2 according to $E$. Drobejar $(1997,22,23)$ - a very popular type in the region spanning from the Spree in eastern Germany to eastern Slovakia (Varsik 2011, 28). The type of feature is the most typical Roman construction in the Germanic milieu in southwestern Slovakia. Typically, a tongue-shaped protrusion/niche in the south-eastern wall is interpreted as an entrance (Kolník 1998, 145). However, it cannot be ruled out that the space where a heating device stood. The latter hypothesis is corroborated by numerous excavations (e.g. Nitra-Párovské Háje) which revealed that exactly on this spot ash accumulated, often in a shallow basin-like recess. An additional post in the feature axis could indicate that the dwelling was reconstructed or that its interior was divided. Similar arrangements are known from other sites (Nitra-Párovské Háje, Branč: Kolník/Varsik/Vladár 2007, fig. 7). Also, in many cases, posts were more densely arranged along the longer middle axis or in the middle of the feature. In the latter case, the post could have been added due to the construction being unstable.

With an internal area of $20.1 \mathrm{~m}^{2}$, the feature belongs to those larger in the Germanic milieu. On the site, there were other sunken houses with areas ranging from 12.5 to $26.2 \mathrm{~m}^{2}$. In sites around Bratislava from 4.5 to $25.5 \mathrm{~m}^{2}$ (Varsik 2011, 30). The house floor was repeatedly smeared with a clayish layer, often unevenly. There was a relatively large number of small (diam. 3-7 cm) pointed holes in the floor. Similar holes are common also on other sites. However, their function is still not satisfactorily explained. The arrangement of the holes provides no clues as to their function. It seems possible that the holes are remains of activities requiring fixing some tools to the floor (yarn spinning?). On the other hand, the holes could drain water from the floor.

The postholes were placed close to the sunken house walls. In the profiles, we were able to identify an original counter of a post (Fig. 4). The posts were flat on the bottom or slightly rounded and their diam. was between 18 and $24 \mathrm{~cm}$. The only exception is posthole no. 3 with a diam. of $62 \mathrm{~cm}$. However, the original contour of the post was not captured. A preliminary analysis of coals indicates that the feature was built of oak.

A heavily charred oval area indicates that there was a fireplace there. Since the floor itself was not charred, it seems unlikely that the house was burnt. On the other side, it is unlikely that there was an open fire in the house without any cover. Indeed, in similar features, portable heating devices were used (Kolník/Varsik/Vladár 2007, 19).

We have no evidence of whether the walls had log or wattle and daub construction. An analogy from Nitra-Párovské Háje corroborates the latter hypothesis. The light could enter the interior through 'sliding windows' in underground parts of the walls.

The most interesting find among bone and antler items is the fragment of the three-layer comb with a semi-circular hand and iron rivets (Fig. 6: 7). Combs are relatively common finds in Germanic graves but appear also in settlements. Due to their chronological sensitivity and aesthetic appeal, 
combs belong to the most important bone and antler products. According to T. Zeman, the comb from Beladice belongs to the largest group of three-layer multi-part combs with semi-circular hands with the toothed middle part fixed by outer plates (Thomas, type I). In this group, decorated specimens are considered younger (Thomas 1960, fig. 27-30; Zeman $2001,113,114)$. The combs appeared from the $3^{\text {rd }} c$. to the mid- $4^{\text {th }} \mathrm{c}$. and only exceptionally in the $5^{\text {th }} \mathrm{c}$. (Kolník 1961, 253, 254; Lamiová-Schmiedlová 1964, 197; Pernička 1967, 72; Thomas 1960, 92; Zeman 2001, 114). The outer plate of the comb from Beladice was decorated with concentric circles arranged in the shape of the letter X. A comb from Krakovany-Stráže had a similar ornament (Zeman 2001, fig. 4: 19).

Bone needles (Fig. 6: 16) with a stick-like butt are present already in the Roman Period stage B2. Since then, we observe a considerable development of needle shapes. At the beginning of the younger Roman Period, in stage C1, stick-like needles were decorated with a mesh or a motif of engraved concentric circles commonly used on combs. Starting from stage C3/D1, needles gradually disappear from the archaeological material (Zeman 2001, 123, 125, fig. 8: 36, 37, 53). Simple bone needles belong to common finds in Germanic settlements. Most likely, their appearance is related to leather and cloth processing.

Previous research showed that homemade production of simple bone and antler items was common in virtually every Germanic settlement. On burial grounds, we find mostly toiletries and fragments of attire. In the Roman Period, the production of such items could be relatively advanced (Zeman 2001, 110). The oldest site with indirect traces of bone processing in Slovakia is a feature from a settlement Nitra-Mikov dated back to the $1^{\text {st }}-2^{\text {nd }} c$., where awls and ready-made bone needles were found (Pieta 1993, 86). Traces of bone processing - raw material, semi-products and waste - were found also in settlements in Abráham (Kolník 1981, 133, 134), Stupava (Turčan 2005, 295), Pobedim (Kolník 1962, 349) and Vajnory (Varsik 2012, 256).

The backfill of the feature contained a considerable number of metal finds. One of the most interesting finds is the iron container, amulet box (Fig. 7), with a bronze wire (chain?) used for locking the item. In the literature, the find is referred to as casket (Kietlińska/Dąbrowska 1963, 191), bronze cylindrical casket (Jaskanis 1977, 304), case (Bursche/Chowaniec 2001, 41), powder box (Bichir 1973, 111). Unlike capsule-shaped pendants (smaller and firmly joint), amulet box can be easily opened and closed. A movable lid is linked with the item by a chain (wire). The wire passing through the box indicates that it did not contain liquids (Fig. 7). Numerous specimens, including the one from Beladice, are decorated. The decorations mainly comprised embossed dots, rounded grooves, zigzag lines (Zemplín, grave 123), concentric circles, rosettes or fish motifs. Some specimens are decorated with miniature bucket-shaped pendants, bells or rings hung to the bottom of the main body of an item. Undecorated specimens are known mainly from Scandinavia and the Wielbark Culture (Czarnecka 2010, 232). They could be part of necklaces, attached to belts or serve as pendants (Czarnecka, 2010, 229) and were used to store various substances or items. Possibly, they had some cult or 'magical' function (Czarnecka 2010, 232). According to Wamers $(2003,620)$, similar containers in the Roman Empire were used to store medical ointments, cosmetics (pigments) or for various cult reasons. Also, in the Barbaricum, they could have similar functions. Most often, they are made of bronze plate and only exceptionally of silver or iron (Bursche 1998, 175, 176; Czarnecka 2010, 229). Thus, the iron specimen from Beladice could be considered unique. So far, we were unable to analyse the capsule contents. Tomography shows that it contained some nonliquid substance. The movable lid indicates that whatever the content was, it could be extracted or replaced. This suggests some perfumes or magical, protective substances.

In Barbaricum, similar items are known from rich female graves (or graves with female equipment) but were found also in children (girls?) graves. There, they are considered imports from the Roman provinces (Kietlińska/Dabrowska 1963, 191). They were worn by children from upper social strata, boys before maturity (?) - toga virilis - but are not strictly related to one cultural milieu. Most commonly, they are found in Scandinavia and the Wielbark Culture. Several items are known from the Elbe region and the Bogaczewo Culture, single items appear in the Przeworsk Culture and among western Germanic peoples. Amulet boxes were found on cemeteries in Karpow attributed to the Poieneşti-Vârteşcoiu Culture. Two specimens are known from Zemplín and are related to the presence of the Dacians. Similar items were found in graves of Sarmatian women in Hungary and Serbia but also Hunnic graves. The majority of amulet boxes - from the Sarmatian milieu to the Scandinavia - are dated back to stages $\mathrm{B} 2 / \mathrm{C} 1-\mathrm{C} 1 \mathrm{a}$ and the beginnings of stage C2 (Czarnecka 2010, 233, fig. 2). Only uniquely, they are attributed to stage B1 (grave 13, Zemplín: BudinskýKrička/Lamiová-Schmiedlová 1990, pl. II: 12, 13) and B2 (grave 123, Zemplín: Peškař 1972, 80). K. Czarnecka mentioned further analogies from younger sites and points to their common presence in the Merovingian $\left(6^{\text {th }}-7^{\text {th }}\right.$ c.) and Anglo-Saxon burial grounds. According to the author, such contain- 
ers are universally used items, present in various regions of the Roman Empire and the Barbaricum (among numerous cultural and ethnic groups from the Sarmatians, Dacians, Germanic peoples to the Balts) and are indicators of female and children (girls) grave furnishings (Czarnecka 2010, 234).

Feature 175 contained four fragments of iron knives (Fig. 5: 17, 18, 20, 21) and a small piece of a fifth blade. Interestingly, there was a fragment of a wooden handle on one of the knives which are rare in our environment (Fig. 5: 20). Apart from the small blade piece, all other finds could be unambiguously attributed to the type of knives most common in Slovakia and the Barbaricum during the Roman Period. Those were even knives with a flat tang and a blade offset at both sides - type 1 according to Droberjar. The blade, however, could be offset at the right angle, obtuse angle or obliquely (Droberjar 1999, 113). Knives, as common tools (or weapons), were used by men and women as confirmed by their presence in both male and female graves. Knives themselves have low chronological value mainly due to their simple shape being relatively stable during longer periods (Lamiová-Schmiedlová 1969, 482). Their dating is possible indirectly thanks to the presence of other finds in a feature (fibulas, bronze vessels or pottery). A find of a collection of knives in combination with craft tools (drill, scalpel?, etc.) indicates that handicraft production - perhaps wood processing - took place close to the feature.

The iron item resembles a 'fork' with two teeth (Fig. 5: 22). However, there is no matching socket. Consequently, the item function remains uncertain. Possibly, it could be part of vehicle construction. So far, we know only one distantly parallel item from Branč (Kolník/Varsik/Vladár 2007, pl. 173: 3).

The bronze needle (Fig. 6: 15) are usually found in the Germanic milieu in settlements and graves. An interesting collection of 33 needles comes from a Germanic settlement in Cífer-Pác, the site 'nad Mlynom' (over the mill). The site is interpreted as a seat of a Quadi, pro-Roman Germanic duke (Kolník 1999, 132-135) dated back to the third and fourth quarter of the $4^{\text {th }}$ c. (Kolník 1986, 419). Most needles - made of bronze - were used for sewing and were 4-10 cm long (Štolcová/Kolník 2010, 481).

The silver/bronze antoninianus (Fig. 6: 6) of Salonina (253-268), Galenius' wife provides important information concerning the dating of the backfill layers. Apparently, the feature decayed not before the second half of the $3^{\text {rd }} \mathrm{c}$. The unique find of the coin of emperor Gallienus' wife may be associated with the conflicts between the Romans and the Germanic people in the ' $50 \mathrm{~s}$ and the ' $60 \mathrm{~s}$ of the $3^{\text {rd }} \mathrm{c}$. (Stoklas 2020,147). As an analogy, we could refer to a hoard of the last silver coins minted during the reign of Gallienus, Salonina coins and Valerian II from the Roman fortified camp Comagena (Tulln, Austria). On that site, there are two catastrophic horizons documented, including one dating back to the year 258 (Stoklas 2020, 146). The Germanic threat was imminent until the mid-' $60 \mathrm{~s}$ of the $3^{\text {rd }} \mathrm{c}$. Finally, there are also records confirming an expedition of Gallienus to Carnuntum. Therefore, it is possible that amidst similar conflicts, the coin as well as other imports could fall into the hands of the Germanic warriors.

Feature 175 contained also a set of glass finds: fragments of vessels and beads (Fig. 6: 9-13). An antique type - the fragment of La Tène bracelet (Fig. 6: 13) was found there as well. It corroborates the view that Celtic products were used during the Roman Period. The fragment of a glass vessel (Fig. 6: 9) could be part of a goblet. Similar goblets made using a similar technique are known both from Cologne and Rome (Hrnčiarik 2013, 61). The square blue glass bead with rounded edges has few parallels (Fig. 6: 11). A smaller green bead from grave 29 on a bi-ritual cemetery from the late Roman Period in Brulino-Koski has a similar shape (Kempisty 1968, fig. 36) and is dated back to phase C1b-C2 (Stawiarska 1987, 88, 89). A distant analogy is provided by a find from Chotín dated back the stage B2/C1-C2 (Březinová 1994, 98).

\section{Pottery}

960 pottery shards were found in the feature. Noteworthy, the collection of pottery is very fragmented with only a few shards matching and only three vessels reconstructed. Predominantly, it is kitchen pottery and is divided into two basic groups: made in hand (93.3\%) and on a potter's wheel (6.7\%). Only 8 shards could be attributed to the prehistoric intrusion.

\section{Local hand-made pottery}

Hand-made pottery is usually referred to as local-Germanic. Among the shards, bowls and pots (or vase-like vessels) predominate. The analysis of rim types shows that the feature contained at least 61 bowls and 46 pots (vase-like vessels). 39.7\% of pottery were made of fine-grain material with an addition of smaller stones (up to $2.6 \mathrm{~mm}$, sometimes also larger). The colours ranged from brown to greyblack with the surface being unsmoothed. $41.5 \%$ of pottery were made from fine-grane material with addition of smaller stones with the smoothed surface (sometimes both sides). $11.1 \%$ of pottery shards were made of a very finer material with smoothed 
- often highly polished surface, usually ranging from grey to black (engobe). The remaining 3\% small bowl-like items - were made of finely-floated material, polished to achieve black-metal gloss. Predominantly, the collection contains smaller vessels, bowls up to $8 \mathrm{~cm}$ high and pots/vessel-like items up to $20 \mathrm{~cm}$. Medium pot-like items ranging from 20 to $30 \mathrm{~cm}$ are rare. Storage pots - larger than $30 \mathrm{~cm}$ - are exceptional (4 vessels). Bowls could be divided into 6 main groups:

- conical with straight, slightly obtuse walls, occasionally with stick-like rim (Varsik IB);

- conical with a slightly inward rim (Pl. I: 6; Varsik IA);

- conical with a clearly inward rim (Varsik IA);

- semi-circular bowls (Varsik IC);

- segmented bowls with a cylindrical neck (Pl. I: 4; Varsik II);

- shallow bowls/plates with a sharp profile and rounded bottom (Varsik II).

Most bowls/cups were rather low. Sharp profiles are rarer while rounded bottoms dominate. There was also one omphalos, which could point to an older settlement horizon from the $2^{\text {nd }} c$. (Beljak 2010b, 145; Knápek/Šedo 2016). Taller, deep bowls with the short neck are typical for the second half of the $2^{\text {nd }} \mathrm{c}$. (Varsik 2011, 59) were absent. Occasionally, there were bowls with a sharp profile and a rounded bottom (Pl. I: 4) characteristic of assemblages dated back to the $2^{\text {nd }} \mathrm{c}$. and the first half of the $3^{\text {rd }} \mathrm{c}$. (Kolnik/ Varsik/Vladár 2007, pl. 3: 12; 8: 9). The vast majority of bowls is undecorated. Very few were decorated with fine grooves, engraved waves, shallow etchings, plastic etched trimmings or mock barbotine (Pl. I: 5). The, geographically, closest example of a real barbotine-decorated item is known from Branč a semi-circular bowl dated back to stages B2, B2/C1 (Kolník/Varsik/Vladár 2007, 25, fig. 21: 1).

Among pots, S-shaped profiled forms with the widest part of the belly around the middle of a pot height, rarer in the upper third, were most common (Varsik IV, resp. Droberjar 1000-1900). Sometimes, the pots were decorated with engraved ornaments (Pl. I: 12, 13; II; III): usually bolder etches, various combinations of notches, crescent and triangle scratches, square punches and branch-like ornaments. Rarely, there were fine (thin) grooves. In one case, the pot was decorated with multiple bundles of waves and sometimes a simple horizontal wave. Larger, oval recesses are typical of younger, Germanic pottery (Kolník/Varsik/Vladár 2005, 316). One of the pots was decorated with a Rädchenverzierung (ger.) triangle (not square) ornaments (Pl. II: 13). Stamping was used in only two cases - a round or slightly oval rosette (Pl. III: 2, 4) with analogies known from a site in Šarovce (Beljak 2010a, fig. 16: 9, 10). This could be a reflection of similar decoration applied on grey Pannonian pottery, which became widespread in northern Pannonia in the third century (Krekovič 1981, 351; Maróti 1990, fig. 1: 18-20) Rims were decorated relatively often (12\%). Usually with various types of oblique grooves and once with a wave. One item was decorated with so-called wolf teeth - i.e. a hatched or punched ornament in the middle of triangle frames.

The function of a coarse-grained cylindrical foot(?) remains unknown. The collection of local pottery contains only a few items typical of the B2 stage. Similarly, we observe no analogies to items typical of the second half of the $4^{\text {th }} \mathrm{c}$. All these corroborate dating the finds back to the $3^{\text {rd }}$ or the first half of the $4^{\text {th }}$ c., i.e. the late Roman Period stages C1 and $\mathrm{C} 2$.

The hand-made zoomorphic vessel (Pl. IV: 1) originally used as an application on some specific vessel - is noteworthy. It resembles a rooster head (part of the comb is missing) with the beak used as the spout. The material indicates the item was locally produced. The closest analogy could be found in Jakuszowice in Poland (Kaczanowski/RodzińskaNowak 2000, fig. 4) in a feature unambiguously dated back to stage C2. The Jakuszowice feature publication refers to numerous analogies (Kaczanowskil Rodzińska-Nowak 2000; Rodzińska-Nowak 2006). The function of this zoomorphic vessel with a spout is unclear. It could be a child's toy. More likely, however, it was related to some cult rituals involving pouring some liquid from a vessel. The latter is further corroborated by the fact that roosters, domestic fowls and, generally, birds were significant aspects of ritual imagery of the Barbarians (Kaczanowskil Rodzińska-Nowak 2000, 110).

\section{Roman provincial pottery}

The smallest group consists of imported Roman provincial vessels. The group could be further divided into 5 subgroups: terra sigillata, Pannonian brick-coloured pottery, Pannonian brown-grey pottery, fine-grained grey pottery and coarse-grained grey pottery.

Terra sigillata is represented by only 9 items (Pl. IV: 1, 3-9), Dragendorf 37 bowls, two egg-and-dart decorated shards (however, in one case, it could be either a poor-quality egg-and-dart decoration or an imperfect stamping). A small, extremely thinwalled shred is most likely a fragment of a cup-like vessel (Pl. IV: 3). One of the shards (Pl. IV: 5) - Westerndorf III belong to the Kempten group. It has not yet been identified from the territory of Barbaricum and is also unknown in the Roman provinces, 
except for Kempten determined by E. Droberjar). According to Kellner, it is related to the Westerndorf III workshop, which is dated to the second part of $3^{\text {rd }}$ c. (Kellner 1962, 124, 125, fig. 1: 4; pl. 8: 4-6). So far, we were unable to classify a small fragment with a relief ornament (Pl. IV: 7). In stage $\mathrm{C} 1$, a considerable import of Westerndorf and Rheinzabern terra sigillata started (Varsik 2011, 31).

Shreds of a Pannonian brown-grey pot comes, most likely, from one ring-bowl with the rim diam. of $21 \mathrm{~cm}$ (Pl. IV: 10), characteristic mostly of the second half of the $2^{\text {nd }}$ c. (Beljak/Kolník 2007, 140) and but also occurs in the $3^{\text {rd }}$ c. (Varsik 2008, 300; 2011, 53, fig. 27) and one small thin-walled bowl (or a cup) with a clearly curved rim with a diam. of $6 \mathrm{~cm}$ (Pl. IV: 12). The other seven shards cannot be assigned to any specific type.

The Pannonian brick-colour pottery is represented by 9 shreds. Original forms cannot be defined. One of the shards is a fragment of a ring-like bottom (diam. $10 \mathrm{~cm}$ ), most likely from a taller jug (Pl. IV: 12).

The find of grey, slightly coarse pottery belongs to the most interesting pottery finds. It is a fragment of a storage vessel with a horizontally curved rim (Pl. IV: 14; Droberjar 2022, in press; Petznek 1998, foldpl. 1: type 3.4). Just below the neck, the vessel was decorated with horizontal lines. Specific forms of those vessels were already at the end of the $2^{\text {nd }} \mathrm{c}$. The most intense development started at the end of the $3^{\text {rd }} \mathrm{c}$. Other shards attributed to this group were decorated with fine grooves on the outside and, generally, clear horizontal lines on the inside. Other 14 shards cannot be linked with any specific type of vessels. Finally, 15 shreds, which cannot be linked with specific types of vessels, represent fine-grained grey well burnt pottery.

The above description shows that - compared to other published assemblages from Slovakia feature 175 contained only a limited amount of pottery imported from Roman provinces (Varsik 2011, 48, tab. 3). This could indicate weak relations with the Roman provinces. However, the so-called small finds (mainly glass and the coin) challenges the hypothesis. Most pottery items belong to relatively long-lived forms (Droberjar 1997, 43; Varsik 2011, 56-68) with the greatest occurrence in the $3^{\text {rd }} \mathrm{c}$. A limited amount of Pannonian pottery could corroborate the view of E. Krekovič concerning the decline of this pottery popularity in stage C2 (Krekovič 1981, 354, 361). A few shards show links with the pottery from the end of the $2^{\text {nd }}$ c. (Rädchenverzierung decoration, barbottino). This applies, for instance, to the reconstructed vessel with analogies from the wooden-soil camp in Iža and the ornaments on small bowls/cups
(Rajtár 2015, 389-391). The entire collection shows no common features with pottery used after the mid- $4^{\text {th }}$ c. (e.g. Turčan 2018, 288-292). E. Droberjar notices that Krausengefä $\beta$ vessels could inform the analysis of products transported in them to the Germanic milieu (Droberjar 2022, in press). Indeed, they were certainly not imported solely as pots. The composition of the ceramic finds indicates that, at least until the last third of the $3^{\text {rd }}$ c., Germanic settlers preferred smaller vessels, usually table ceramics. Rarely, they used ceramic vessels for storage or transport. For those purposes, they clearly used other, possibly wooden containers or leather bags. Primarily, the pottery found in Beladice was used for dining. Less often it was used for cooking and only exceptionally for food storage or transport.

\section{CHRONOLOGY}

The vast majority of the finds come from the feature backfill and, most likely, are unrelated to the feature original function. Some of them seem to reflect the developments in the second half of the $2^{\text {nd }} \mathrm{c}$. (roulette decoration, omphalos). However, the finds show little resemblance to assemblages dated back to the end of the $2^{\text {nd }} c$. (Beljak 2010b, 146). Large amounts of the pottery have its origin in C1-C2 in the Danube region (Varsik 2011, fig. 27) and central Bohemia region (Droberjar/Prostředník 2004, pl. 22) Informed by typological analogies and the Saloninas (†268) antoninianus - which marks at least the lower time bound - we can determine that the inventory was put in the backfill, roughly, in the third quarter of the $3^{\text {rd }} \mathrm{c}$. or first half (closer to the beginning) of the $4^{\text {th }} \mathrm{c}$. The decay, thus, could be related to stages $\mathrm{C} 2 / \mathrm{C} 3$ (according to Godłowski) or the early phase of stage C3 (according to Tejral) of the Roman Period chronology.

\section{The Bocegaj valley in Roman Times}

The research in Beladice as well as other researchers over the last 40 years fundamentally changed our understanding of the Upper Vah region in the first half of the first millennium. Although the still widely used settlement map published in 1998 shows four settled areas (Rajtár 1998, map 2), now we are aware of the existence of 64 . Also, in the Bocegaj valley, archaeological sites are relatively densely distributed. Approximately 1,800 $\mathrm{m}$ to the east, on a north-facing slope over the confluence of the Bocegaj and the Drevenica, there are clear traces of a settlement certainly attributable also to the $2^{\text {nd }} \mathrm{c}$. 
(Ruttkay/Ruttkayová 1992, 92). Another site is located to the north, on the left bank of the Bocegaj creek (Ruttkay/Ruttkayová 1992, 92). $100 \mathrm{~m}$ to the southeast of the reservoir and 100-200 $\mathrm{m}$ to the south of the creek, on the right bank of the Bocegaj, a large collection of wheel-made pottery, imported terra sigillata and somehow fewer examples of hand-made Germanic pottery were found (Bednár/Ruttkay 1991, 27). Approximately $800-1,300 \mathrm{~m}$ to the east of the Baratsko grange, on the right bank of the Bocegaj, there is another site attributed to Roman times with Roman Period wheel-made pottery (Ruttkayl Ruttkayová 1992, 92). A similar density of Germanic settlements is observed in most parts of the Upper Vah region (Ruttkayová/Ruttkay 2015, 30).

Two Roman marching camps were found on the southern bound of the Upper Žitava region, only $12 \mathrm{~km}$ to the south of the Beladice site (Bátora et al. 2012). Perhaps, it is just a matter of time, when, as T. Kolník expects similar camps will be discovered in the Nitra region (only $15 \mathrm{~km}$ to the west of Beladice) or the Vah region in the Želiezovce - Šarovce area ( $35 \mathrm{~km}$ to the south-east) with a considerable concentration of finds dated back to the $2^{\text {nd }}$ and $3^{\text {rd }} \mathrm{c}$. During the Marcomannic wars at the end of the $2^{\text {nd }} c$., Roman marching camps in the Žitava region were used to control lands with a denser Germanic settlement. The settlement density in the $3^{\text {rd }} \mathrm{c}$. in the Žitava region indicates that the Romans' presence there had had no long-term effects and the Germanic settlement flourished. Consequently, we can conclude that the Upper Žitava region - compared to other parts of the Danube region - was extremely densely settled from the mid-Roman Period until the Migration Period.

\section{CONCLUSIONS}

Feature 175 from the Beladice site researched in 2009 and 2010 provided a relatively large collection of finds that shed light on the life of the Germanic community in the $3^{\text {rd }} \mathrm{c}$. Numerous imports in the feature itself and other features on the site indicate that the Germanic people maintained intense contacts (either in a state of conflict or peace) with the
Roman provinces. The presence of fragments of glass vessels and a large number of smaller vessels - certainly elements of the tableware - shows that the Germanic people put great emphasis on the dining quality. Possibly including wine consumption (Varsik 2009). The unrest that disturbed the northern border of the Roman Empire after the mid- $3^{\text {rd }} c$. suggests that, probably, products from the Roman provinces could get into the Žitava region through the war-time looting.

The investigated sunken house (hut) was a standard dwelling in the early Roman Period. The finds indicate that the backfill contained artefacts from the next period - from the end of the $2^{\text {nd }} c$. to, most likely, the beginning of the $4^{\text {th }} \mathrm{c}$. A minimum number of prehistoric finds (despite the frequent occurrence of prehistoric features in the area) indicates that the feature was gradually backfilled after it had decayed (no distinct layers were observed). The relatively large collection of pottery and small finds point to the variability of the material culture and the predilection for imported items - either glass or metal products. Two finds deserve exceptional attention: the zoomorphic vessel depicting a rooster head and the iron capsule. Both could have magical functions but we cannot preclude that the capsule was used also for storing fragrant substances. Ceramic finds indicate that the inhabitants preferred smaller vessels, most likely used for dining. Supplies were stored rather in wooden containers or leather bags. The feature analysed here helps to reconstruct the Germanic people lives in the early Roman Times in the Upper Žitava region.

The feature, as well as the entire site, supplements the dense Germanic settlement network in the Upper Žitava region from the mid- $2^{\text {nd }} \mathrm{c}$. to the turn of the $4^{\text {th }}$ and $5^{\text {th }}$ c. This questions older claims about the only sporadic presence of the Germanic people in the area. The abundance of sites in this relatively small area shows a radically different picture. Possibly also this dense settlement network contributed to the decision about building two Roman marching camps in nearby Vráble at the end of the $2^{\text {nd }} \mathrm{c}$. The presence of the camps, however, did not interfere with the development of the Germanic settlement activities. 

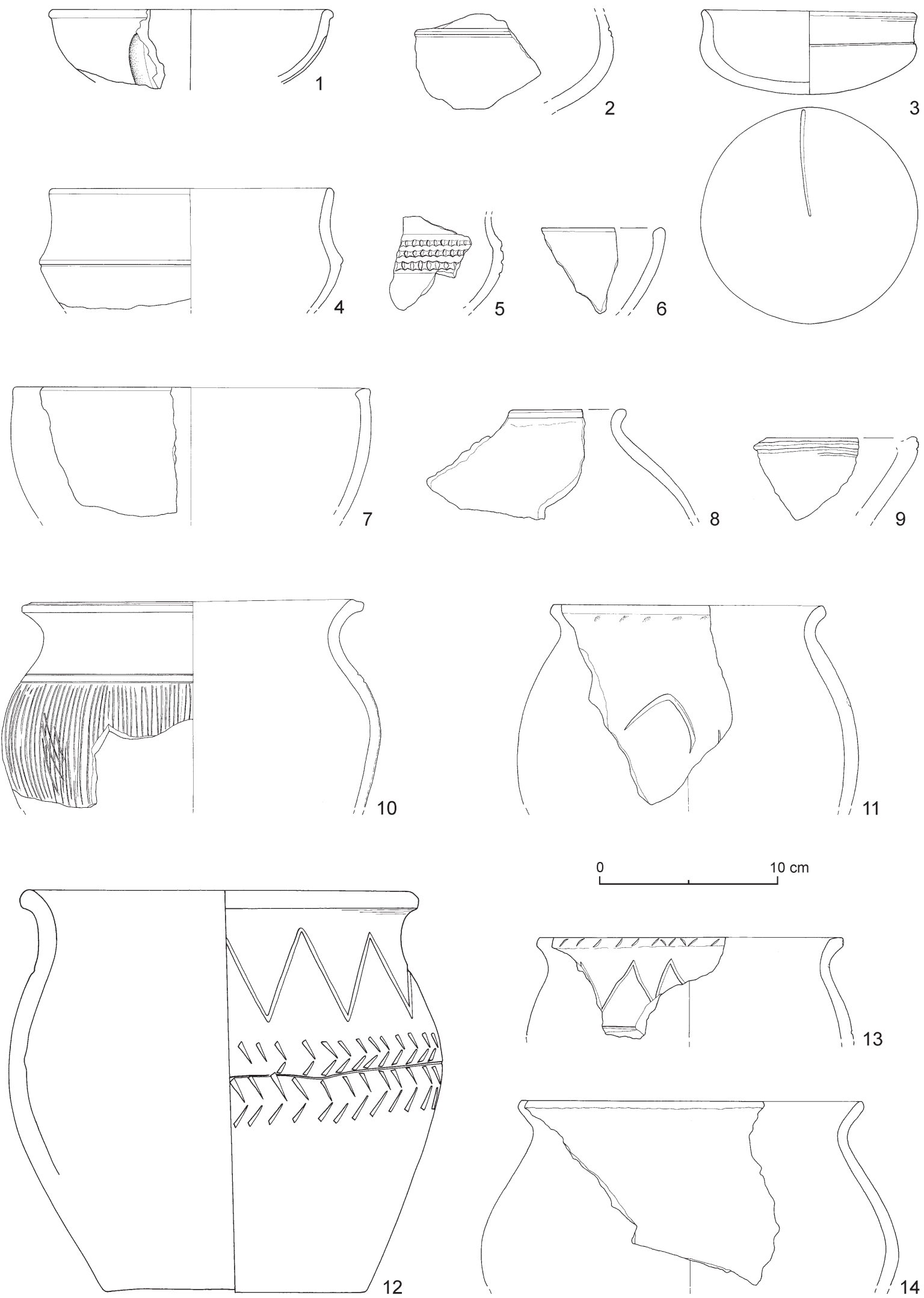

13

12

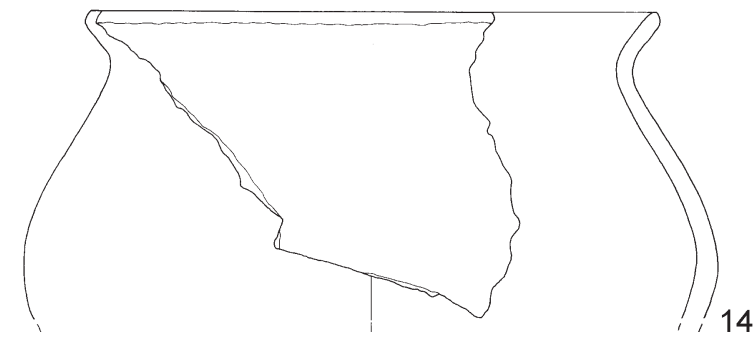

Pl. I. Beladice. Feature no. 175. Hand-made pottery. 

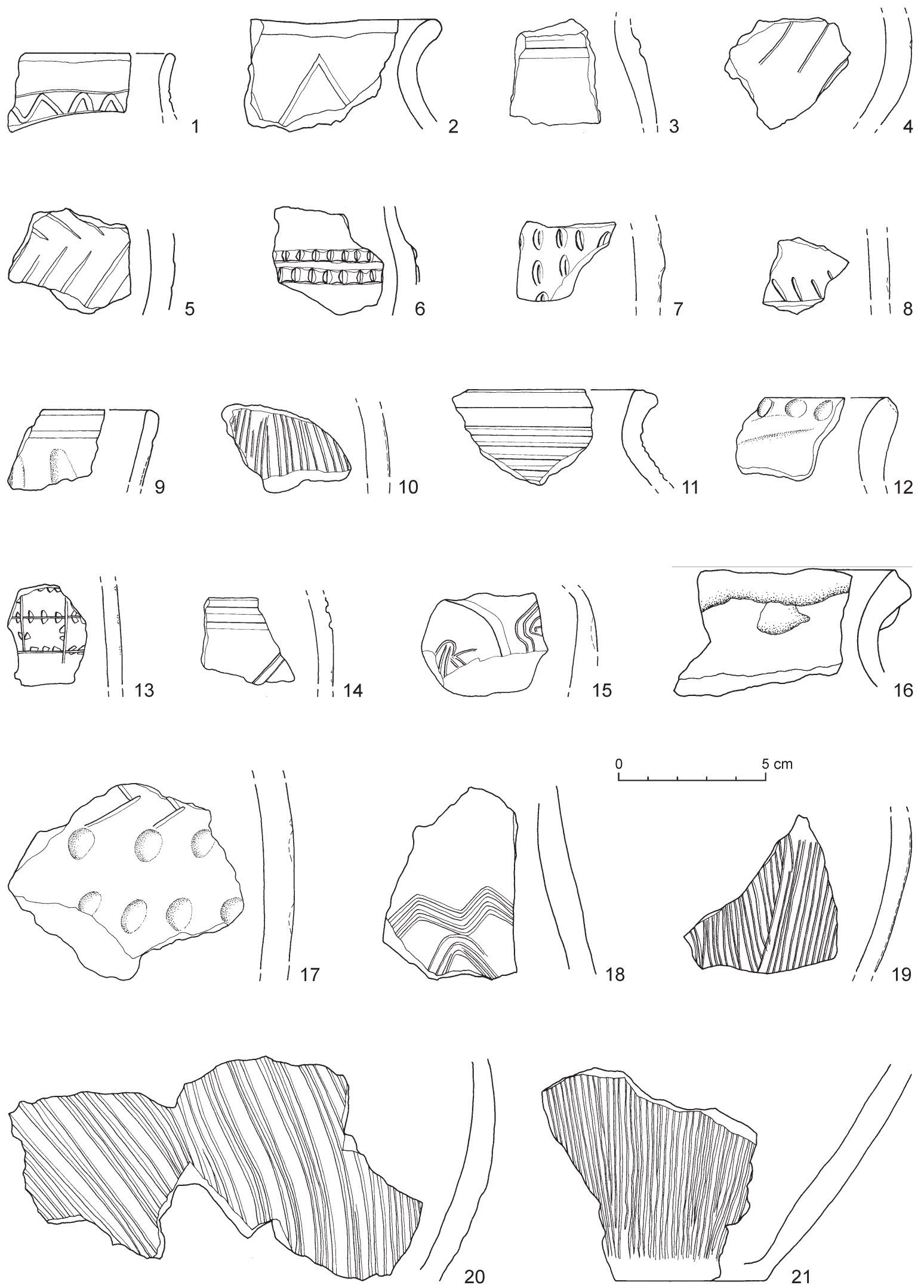

Pl. II. Beladice. Feature no. 175. Hand-made pottery, decoration variants. 


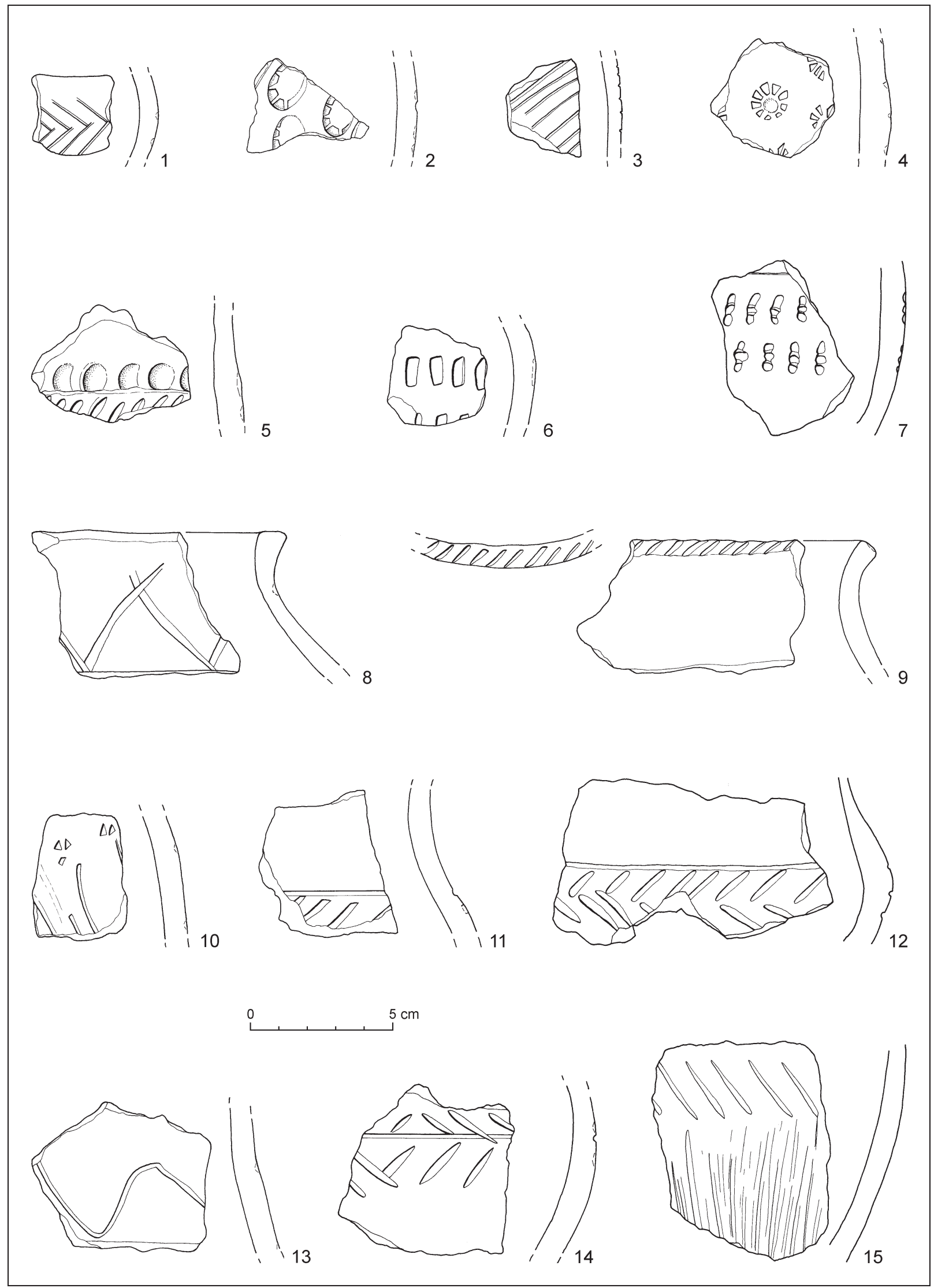

Pl. III. Beladice. Feature no. 175. Hand-made pottery, decoration variants. 


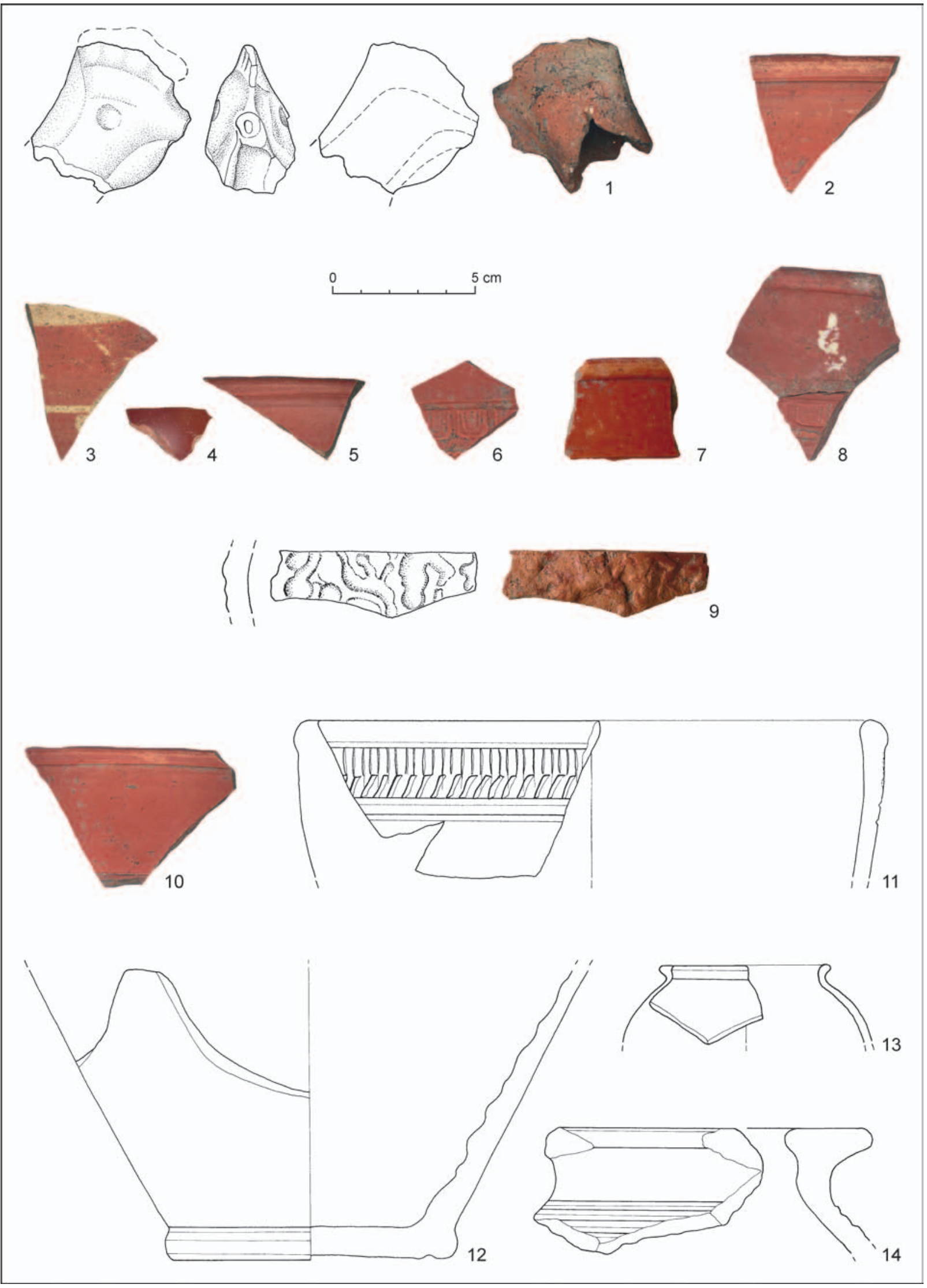

Pl. IV. Beladice. Feature no. 175. 1 - hand-made pottery; 2-14 - Roman provincial pottery. 


\section{BIBLIOGRAPHY}

Bátora et al. 2012 - J. Bátora/A. Behrens/J. Gresky/ M. Ivanova/ K. Rassmann/P. Tóth/K. Winkelmann: The Rise and Decline of the Early Bronze Age Settlement Fidvár near Vráble, Slovakia. In: J. Kneisel/ W. Kirleis/M. D. Corso/N. Taylor/V. Tiedtke (eds.): Collapse or Continuity? Environment and Development of Bronze Age Human Landscapes. Proceedings of the International Workshop "Socio-Environmental Dynamics over the Last 12,000 Years. The Creation of Landscapes II $\left(14^{\text {th }}-18^{\text {th }}\right.$ March 2011)" in Kiel. Volume 1. Universitätsforschungen zur prähistorischen Archäologie 205. Bonn 2012, 111-129.

Bednár/Ruttkay 1991 - P. Bednár/M. Ruttkay: Prieskum povodia potoka Bocegaj. AVANS 1989, 1991, 26-28.

Beljak 2010a - J. Beljak: Germánska osada v Šarovciach. J. Beljak/G. Březinová/V. Varsik (eds.): Archeológia barbarov 2009. Hospodárstvo Germánov, sídliskové a ekonomické štruktúry od neskorej doby laténskej po včasný stredovek. Zborník referátov z 5. protohistorickej konferencie. Nitra 21.-25. septembra 2009. Archaeologica Slovaca Monographiae. Communicationes 10. Nitra 2010, 33-66.

Beljak 2010b - J. Beljak: Germánske osídlenie v Štúrove a na Dolnom Pohroní v staršej dobe rímskej. Zborník SNM 104. Archeológia 20, 2010, 141-173.

Beljak/Kolník 2007 - J. Beljak/T. Kolník: Rímskoprovinciálna keramika z germánskej osady v Štúrove. In: E. Droberjar/O. Chvojka (eds.): Archeologie barbarů 2006. Sborník př́spěvků z II. protohistorické konference (České Budějovice, 21.-24. 11. 2006). Archeologické výzkumy v jižních Čechách. Supplement 3. České Budějovice 2007, 135-157.

Bichir 1973 - G. Bichir: Cultura carpică. Bucureşti. 1973. Březinová 1994 - G. Březinová: Sklené nálezy z Chotína. Študijné zvesti Aú SAV 30, 1994, 97-106.

Budinský-Krička/Lamiová-Schmiedlová 1990 - V. Budinský-Krička/M. Lamiová-Schmiedlová: A late $1^{\text {st }}$ century B.C. $-2^{\text {nd }}$ century A.D. Cemetery at Zemplín. Slovenská archeológia 38, 1990, 245-341.

Bursche 1998 - A. Bursche: Złote medaliony rzymskie $w$ Barbaricum. Symbolika prestiżu $i$ władzy społeczeństw barbarzyńskich u schyłku starożytności. Światowit. Supplement Series A. Antiquity 2. Warszawa 1998.

Bursche/Chowaniec 2001 - A. Bursche/R. Chowaniec: Puzderko brązowe z cmetarzyska kultury wielbarskiej w Krośnie, powiat pasłęcki. In: W. Nowakowski/ A. Szela (eds.): Officina archaeologica optima. Studia ofiarowane Jerzemu Okuliczowi-Kozarynowi w siedemdziesiata rocznice urodzin. Światowit. Supplement Series P. Prehistory and Middle Ages 7. Warszawa 2001, 41-45.

Czarnecka 2010 - K. Czarnecka: Metalowe pojemniczki tzw. Amulettendose w europejskim Barbaricum. In: A. Urbaniak/R. Prochowicz (red.): Terra Barbarica. Studia ofiarowane Magdalenie Maczyńskiej w 65. rocznice urodzin. Monumenta Archaeologica Barbarica. Series Gemina 2. Łódź - Warszawa 2010, 229-238.
Droberjar 1997 - E. Droberjar: Studien zu den germanischen Siedlungen der älteren römischen Kaiserzeit in Mähren. Fontes Archaeologici Pragenses 21. Praha 1997.

Droberjar 1999 - E. Droberjar: Dobřichov-Pičhora. Ein Brandgräberfeld der ältern römischen Kaiserzeit in Böhmen. (Ein Beitrag zur Kenntnis des Marbod-Reichs.) Fontes Archaeologici Pragenses 23. Praha 1999.

Droberjar 2022, in press - E. Droberjar: K významu římsko-provinciálních zásobnic s okružím (Krausengefäße) ze 2. století v Jevíčku v kontextu nadunajského Barbarika. Přehled výzkumů, in press.

Droberjar/Prostředník 2004 - E. Droberjar/J. Prostředník: Turnov-Maškovy zahrady - germánský dvorec ze 3. století. Památky archeologické 95, 2004, 31-106.

Hrnčiarik 2013 - E. Hrnčiarik: Römisches Kulturgut in der Slowakei. Herstellung, Funktion und Export römischer Manufakturerzeugnisse aus den Provinzen in der Slowakei. Universitätsforschungen zur prähistorischen Archäologie 222. Bonn 2013.

Jaskanis 1977 - J. Jaskanis: Cmentarzyska kultury zachodniobałtyjskiej z okresu wpływów rzymskich. Materiały do badań nad obrządkiem pogrzebowym. Materiały Starożytne i Wczesnośredniowieczne 4, 1977, 239-350.

Kaczanowski/Rodzińska-Nowak 2000 - P. Kaczanowski/ J. Rodzińska-Nowak: Tonplastik von der Siedlung der Przeworsk-Kultur in Jakuszowice, Fundstelle 2, Gemeinde Kazimierza Wielka. In: J. Bouzek/ H. Friesinger/K. Pieta/B. Komoróczy (Hrsg.): Gentes, Reges und Rom. Auseinandersetzung-Anmerkung-Anpassung. Festschrift für Jaroslav Tejral zum 65. Gegurtstag. Spisy Archeologického ústavu AV ČR Brno 16. Brno 2000, 107-115.

Kellner 1962 - H.-J. Kellner: Die raetischen SigillataTöpfereien und ihr Verhältnis zu Westerndorf. Zur Sigillata-Töpferei von Westerndorf III. Bayerische Vorgeschichtsblätter 27, 1962, 115-129.

Kempisty 1966-1967 - A. Kempisty: Birytualne cmentarzysko z póznego okresu rzymskiego w miejscowości Brulino-Koski, pow. Ostrów Mazowiecka. Wiadomości Archeologiczne 32, 1966-1967, 409-450.

Kietlińska/Dąbrowska 1963 - A. Kietlińska/T. Dąbrowska: Cmentarzysko z okresu wplywów rzymskich we wsi Spicymierz, pow. Turek. Materiały Starożytne 9, 1963, 143-254.

Knápek/Šedo 2016 - R. Knápek/O. Šedo: Misky s omfalem v živote barbarských společností doby římské. Zborník SNM 110. Archeológia 26, 2016, 221-279.

Kolník 1961 - T. Kolník: Pohrebisko v Bešeňove (príspevok k štúdiu doby rímskej na Slovensku). Slovenská archeológia 9, 1961, 219-300.

Kolník 1962 - T. Kolník: Nové sídliskové nálezy z doby rímskej na Slovensku. Archeologické rozhledy 14, 1962, 344-397.

Kolník 1981 - T. Kolník: Sídliskové nálezy z doby rímskej v Abraháme. AVANS 1980, 1981, 133-135.

Kolník 1986 - T. Kolník: Römische Stationen im slowakischen Abschnitt des nordpannonischen Limes- 
vorlandes. Archeologické rozhledy 38, 1986, 411-434, 467-472.

Kolník 1998 - T. Kolník: Haus und Hof im quadischen Limesvorland. In: A. Leube (Hrsg.): Haus und Hof im östlichen Germanien. Tagung Berlin 4. bis 8. Oktober 1994. Universitätsforschungen zur prähistorischen Archäologie 50. Schriften zur Archäologie der germanischen und slawischen Frühgeschichte 2. Bonn 1998, 144-159.

Kolník 1999 - T. Kolník: Nordpannonische Limesvorland-Forschung 1984-1986. In: N. Gudea (ed.): Roman Frontier Studies Proceedings of the XVII ${ }^{\text {th }}$ Frontier Studies. Zalău 1999, 131-137.

Kolník/Varsik/Vladár 2005 - T. Kolník/V. Varsik/J. Vladár: Nálezové súbory z germánskych sídlisk na juhozápadnom Slovensku s prítomnostou mincí z druhej polovice 3. storočia. Branč, objekt 60. Zborník SNM 99. Archeológia 15, 2005, 313-323.

Kolník/Varsik/Vladár 2007 - T. Kolník/V. Varsik/J. Vladár: Branč. Germánska osada z 2. až 4. storočia. Archaeologica Slovaca Monographiae. Catalogi 10. Nitra 2007.

Krekovič 1981 - E. Krekovič: Rímska importovaná keramika na Slovensku. Slovenská archeológia 29, 1981, 341-376.

Lamiová-Schmiedlová 1964 - M. Lamiová-Schmiedlová: Hrebene z doby rímskej a st’ahovania národov z východného Slovenska. Archeologické studijní materiály I, 1964, 191-201.

Lamiová-Schmiedlová 1969 - M. Lamiová-Schmiedlová: Römerzeitliche Siedlungskeramik in der Südostslowakei. Slovenská archeológia 17, 1969, 403-502.

Leube 2009 - A. Leube: Studien zu Wirtschaft und Siedlung bei den germanischen Stämmmen im nördlichen Mitteleuropa während des 1. bis 5./6. Jahrhunderts n. Chr. Römisch-Germanische Forschungen 64. Mainz am Rhein 2009.

Maróti 1990 - É. Maróti: Pannonische Glanztonware mit Stempelverzierung von Zalalövő. Acta Archaeologica Academiae Scientiarum Hungaricae 42, 1990, 97-110.

Pernička 1967 - R. M. Pernička: K problematice středoevropského vývoje hřebenů v době laténské a římské se zvláštním zřetelem k moravským nálezům. Sborník prací Filozofické fakulty brněnské univerzity. Ǩada archeologicko-klasická E12, 1967, 63-79.

Peškař 1972 - I. Peškař: Fibeln aus der römischen Kaiserzeit in Mähren. Praha 1972.

Petznek 1998 - B. Petznek: Römerzeitliche Gebrauchskeramik aus Carnuntum. Ausgrabungen des Bundesdenkmalamtes 1971 bis 1972. Teil 1. Carnuntum Jahrbuch 1997, 1998, 167-323.

Pieta 1993 - K. Pieta: Osídlenie z doby rímskej a stahovania národov v Nitre. In: K. Pieta (ed.): Nitra. Príspevky k najstarším dejinám mesta. Nitra 1993, 74-91.

Pieta/Ruttkay 1997 - K. Pieta/M. Ruttkay: Germanische Siedlung aus dem 4. und 5. Jh. in Nitra-Párovské háje und Probleme der Siedlungskontinuität. In: J. Tejral/H. Friesinger/M. Kazanski (Hrsg.): Neue Beiträge zur Erforschung der Spätantike im mittleren Donauraum. Spisy Archeologického ústavu AV ČR Brno 8. Brno 1997, 145-163.
Rajtár 1998 - J. Rajtár: Kríza rímsko-germánskych vzt’ahov $v$ stredodunajskej oblasti v 2. storočí. Dizertačná práca. Archeologický ústav SAV Nitra. Nitra 1998. Unpublished.

Rajtár 2015 - J. Rajtár: Germánske nálezy z rímskeho drevozemného tábora v Iži. Zborník SNM 109. Archeológia 25, 2015, 379-399.

Rodzińska-Nowak 2006 - J. Rodzińska-Nowak: Zoomorficzna plastyka figuralna z cmentarzysk kultury przeworskiej. In: L. Kostuch/K. Ryszewska (red.): Zwierze jako sacrum w pradziejach $i$ starożytności $I$. Kielce 2006, 11-26.

Ruttkay et al. 2015: M. Ruttkay/A. Bistáková/K. Daňová/ M. Gabulová/M. Cheben/R. Malček: Záchranné archeologické výskumy na trase výstavby rýchlostnej cesty R1 v úseku Nitra-Selenec - Beladice. AVANS 2010, 2015, 211-215.

Ruttkay/Ruttkayová 1992 - M. Ruttkay/J. Ruttkayová: Pokračovanie výskumu horného Považia. AVANS 1990, 1992, 91-93.

Ruttkayová/Ruttkay 2015 - J. Ruttkayová/M. Ruttkay: Horné Požitavie. Svedectvo archeológie. Archaeologica Slovaca Monographiae. Varia 5. Nitra 2015.

Stawiarska 1987 - T. Stawiarska: Katalog paciorków szklanych z obszaru Polski pótnocnej w okresie wpływów rzymskich. Wrocław-Warszawa-Kraków-Gdańsk-Łódź 1987.

Stoklas 2020 - B. Stoklas: Začiatok hospodárskej krízy rímskeho impéria $v$ konfrontácii s nálezmi antoniniánov v 2.-3. storočí po Kristovi na území Čiech, Moravy, Slovenska, Horného a Dolného Rakúska a Mad'arska. Dizertačná práca. Univerzita Hradec Králové. Filozofická fakulta. Katedra archeologie. Hradec Králové 2020. Online available at: https://theses.cz/id/tebe7w/ Štolcová/Kolník 2010 - T. Štolcová/T. Kolník: Tkáčske dielne z neskorej doby rímskej v Cíferi-Páci. In: J. Beljak/G. Březinová/V. Varsik (eds.): Archeológia barbarov 2009. Hospodárstvo Germánov, sídliskové a ekonomické štruktúry od neskorej doby laténskej po včasný stredovek. Zborník referátov z 5. protohistorickej konferencie. Nitra 21.-25. septembra 2009. Archaeologica Slovaca Monographiae. Communicationes 10. Nitra 2010, 467-487.

Thomas 1960 - E. Thomas: Studien zu den germanischen Kämmen der römischen Kaiserzeit. Arbeits- und Forschungsberichte zur sächsischen Bodendenkmalpflege 8, 1960, 54-215.

Turčan 2005 - V. Turčan: Nálezové súbory z germánskych sídlisk na juhozápadnom Slovensku s prítomnost’ou mincí z druhej polovice 3. storočia. Objekt č. 1/96 zo Stupavy, poloha Morávkovo pole. Zborník SNM 99. Archeológia 15, 2005, 293-300.

Turčan 2018 - V. Turčan: Germánsky sídliskový objekt z Dunajskej Lužnej. Zborník SNM 112. Archeológia 28, 2018, 287-300.

Varsik 2008 - V. Varsik: Germánske sídliskové objekty z doby rímskej datované terrou sigillatou do doby Severovcov. Nálezové súbory z germánskych sídlisk sprevádzané severovskou terrou sigillatou. Vel'ký Med’er, objekt 106. Zborník SNM 102. Archeológia 18, 2008, 293-306. 
Varsik 2009 - V. Varsik: Rímske sklo z niektorých germánskych sídlisk na západnom Slovensku. Študijné zvesti Aú SAV 45, 2009, 133-150.

Varsik 2011 - V. Varsik: Germánske osídlenie na východnom predpolí Bratislavy. Sídliská z doby rímskej v Bratislave-Trnávke a v okolí. Archaeologica Slovaca Monographiae. Fontes 18. Nitra 2011.

Varsik 2012 - V. Varsik: Hospodárstvo Germánov v bratislavskom priestore. In: J. Šedivý/T. Štefanovičová (zost.): Dejiny Bratislavy 1. Od počiatkov do prelomu

Manuscript accepted 30. 9. 2021

Translated by Magdalena Adamus

PhDr. Jaroslava Ruttkayová Ponitrianske múzeum v Nitre Štefánikova 1 SK - 94901 Nitra jaroslava.ruttkayova@gmail.com
12. a 13. storočia. Brezalauspurc na križovatke kultúr. Bratislava 2012, 254-256.

Wamers 2003 - E. Wamers: Pyxis. In: H. v. Beck/D. Geuenich/H. Steuer (Hrsg.): Reallexikon der Germanischen Altertumskunde 23. Berlin - New York 2003, 620-624.

Zeman 2001 - T. Zeman: Germánska kostěná a parohová industrie doby římské ve středoevropském barbariku. Sborník prací Filozofické fakulty brněnské univerzity. Řada archeologická M6, 2001, 107-147.

doc. PhDr. Matej Ruttkay, CSc.

Archeologický ústav SAV

Akademická 2

SK - 94921 Nitra

matej.ruttkay@savba.sk 